\title{
Production efficiency of Inpago Unsoed-1 and Situbagendit rice farming in Central Java, Indonesia
}

\author{
ALTRI MULYANI ${ }^{1,2, \bullet}$, DWIDJONO HADI DARWANTO ${ }^{3}$, SRI WIDODO ${ }^{3}$, MASYHURI ${ }^{3}$ \\ ${ }^{1}$ Faculty of Agriculture, Universitas Jenderal Soedirman. Jl. Dr. Suparno No. 63, Purwokerto Utara, Banyumas 53122, Central Java, Indonesia \\ Tel./fax.: +62-281-638791, "email: altri.unsoed@ gmail.com \\ ${ }^{2}$ Agricultural Science Graduate Program, Faculty of Agriculture, Universitas Gadjah Mada. Jl. Flora No. 1, Sleman 55281, Yogyakarta, Indonesia \\ ${ }^{3}$ Department of Agricultural Socioeconomics, Faculty of Agriculture, Universitas Gadjah Mada. J1. Flora No. 1, Sleman 55281, Yogyakarta, Indonesia
}

Manuscript received: 12 March 2020. Revision accepted: 25 June 2020.

\begin{abstract}
Mulyani A, Darwanto D, Widodo S, Masyuri. 2020. Production efficiency of Inpago Unsoed-1 and Situbagendit rice farming in Central Java, Indonesia. Biodiversitas 12: 3276-3286. Inpago Unsoed-1 rice is a new superior rice variety that is not as familiar as Situbagendit variety for farmers in Indonesia. As one of the new superior rice variety, Inpago Unsoed-1 is expected to improve farm business efficiency so that it can increase farmers' income. This study was conducted to figure out the factors influencing the production of Inpago Unsoed-1 and Situbagendit rice in Province of Central Java, and to recognize the level of technical, allocative and economic efficiencies of Inpago Unsoed-1 and Situbagendit rice farming in Province of Central Java. Research sites included selected regencies in Province of Central Jawa, such as Banyumas, Purbalingga, and Cilacap. Meanwhile, the selected districts were Kalibagor (Banyumas); Kalimanah, Kemangkon, Bukateja, Kutasari, Kaligondang, and Bobotsari (Purbalingga); and Gandrungmangu (Cilacap). Data were collected by direct observation and interviews using semi-structured questionnaire. The sampling technique used non-probability sampling using a purposive sampling method. Data were collected during December 2018-May 2019, 147 farmers were sampled, consisting of 71 and 76 farmers for Inpago Unsoed-1 and Situbagendit, respectively. Data were analyzed by using Cobb-Douglas production function and function of Stochastic Frontier. The results showed that production factors of land acreage (ha) and P fertilizer $(\mathrm{kg})$ positively affected the production of Inpago Unsoed-1 rice, whereas seeds ( $\mathrm{kg}$ ), N fertilizer ( $\mathrm{kg}$ ) and pesticide (l) had negative impact on its production. On Situbagendit rice production, the positive and negative effects were revealed by land acreage (ha) as well as pesticide (1) and $\mathrm{N}$ fertilizer $(\mathrm{kg})$, respectively. Technical, economic, and allocative efficiencies on Inpago Unsoed-1 rice farming were $0.75,0.65$, and 0.88 , respectively, which were higher than those of Situbagendit, i.e. $0.73,0.54$ and 0.75 , respectively.
\end{abstract}

Keywords: Cobb-Douglas, efficiency, Inpago Unsoed-1, Situbagendit, stochastic frontier

\section{INTRODUCTION}

Rice is a strategic commodity for Indonesia and the main food for most of Indonesia population, it is very important to maintain food security of this country. In order to meet its significant increasing demand due to population growth, its productivity should be also significantly improved. However, most of rice production in Indonesia encounter constraints such as limited resources. Other aspects are low adoption and dissemination of modern technology, so that the farmers do not get the benefit from modern technology. Nguyen et al. (2012) summarized that a pre-requirement for improvement was good understanding of factors determining efficiency.

The increment of economic efficiency in agriculture is the most essential factor for the growth of rice productivity, particularly in developing countries with poor resources and fewer chances for developing and adopting better technology. The important source for agricultural sector is the increase of efficiency through larger technical and allocative efficiencies by producer. Many resource limitations are faced by farmers in developing countries like Indonesia, one of them is land. In Indonesia, agricultural land is decreasing every year due to its functional shift to settlements and other sectors. Therefore, the improvement in agricultural production should be gained by increasing land productivity through one or more input combinations such as technology, number, and type of used resources and efficiency in the use of the resources.

Embarking on new technologies likely green revolution is meaningless unless the existing technology is used to its full potential (Kalirajan et al. 1996). Of the various determinants, improvement in the efficiency of the resources already at the disposal of the farmers is of great concern. Hence, raising efficiency offers more immediate goals at modest costs if there are substantial inefficiencies present in agricultural production (Goyal et al. 2006). Inefficiencies in food farming are still faced by many developing countries, including Indonesia. Inefficiency is still an interesting topic for further study. The research related factors that influence inefficiencies such as Rashid (2016) examines factors affecting rice production and technical efficiency in the context of SLPHT (Integrated Pest Control Field School/Integrated Pest Control Field School) (Bhattacharyya et al. 2016; Samarphita 2016; Kerdsriserm et al. 2018; Wibowo et al. 2019). The concept of efficiency also is applied in other fields such as Efani et al. (2019) research on tuna fishing. 
The estimation of efficiency level can assist the farmers in deciding whether or not to increase the efficiency or to develop new technology to improve agricultural production. One of applicable new technology in increment of land productivity is the use of superior variety seeds. Inpago Unsoed-1 rice is one of superior seeds for increasing land productivity. The increase in efficiency can be also performed by correcting the managerial capability of farmers. This capability may originate from their self and institution as well. Farmer managerial capabilities affecting efficiency are socio-economic factors such as age, farming experience, formal education level, informal education through cultivation, and farming management. Institutional factors influencing efficiency involves the membership in farmer group, access to field agriculture instructor (PPL), access to financial support for farming, etc. (Lubis 2000). Knowledge of the factors that affect the technical efficiency of farming is needed by farmers to develop their farming. Some factors related to production efficiency issues are (i) farmers economizing behavior, (ii) factors contributing to technical efficiency, and (iii) socioeconomic factors influencing technical efficiency. The research related to farm efficiency including research by (Feng 2008; Nezhad et al. 2012; Coventry et al. 2015; Addison et al. 2016; Zhang et al. 2016, Nguyen 2017; Achandi 2018; Paul \& Shankar 2018; Chandio et al. 2019; Kouyate et al. 2019). Gong et al. (2019); investigate technical efficiency in crop production comparing family farms that are members of cooperatives, either as core members who have taken investment stakes or common members who have not, with their nonmember counterparts. The results showed that nonmember farms had the lowest technical efficiency and a large gap between real and potential production.

Inpago Unsoed-1 rice is new superior variety which has been recognized as national superior rice variety by Ministry of Agriculture, Republic of Indonesia under Decree No. 3165/Kpts/SR.120/7/2011 date of 4 July 2011 and Certificate of PVT (Plant Varietal Protection) Right No.00233/PPVT/S/2013 date of 12 November 2013. Its superiorities are yield potency of up to 10 ton/ha in paddy field (wetland) and 7.2 ton/ha in dryland, short maturity of 90 days after planting, fluffier and aromatic rice texture, resistant to blast pathogen race 133 , relatively resistant to brown rice planthopper biotype 1, resistant to drought, and responsive to organic cultivation (Laboratory of Plant Breeding and Biotechnology Unsoed 2011). As a new variety, its superiorities are not widely known by farmers in Province of Central Java. Most farmers in this area plant other popular rice varieties such as Situbagendit. It is not easy to change from commonly planted varieties because farmers worry about the lower-income due to adopting new varieties. They will accept a new technology when it can provide higher income than the existing one.

Variety of Situbagendit is one of well-known rice varieties in farmers of Province of Central Java, so that its adaptability to environment and cultivation technology is also relatively easier. This will be related to efficiency of its farming. The long experience in cultivation of Situbagendit variety will help the farmers in improving the efficiency of farming. It differs from newly recognized rice variety. Farmer adaptation like cultivation treatment is adjusted to the characters of that new variety. Inpago Unsoed-1 is one of superior rice varieties and it is not familiar for farmers in Province of Central Java. As a new variety, many farmers do not know its superiorities rather than other rice varieties. As a superior variety, Inpago Unsoed-1 is expected to increase the efficiency of farming and the income of farmers. Thus, it is important to study the efficiency of Inpago Unsoed-1 and Situbagendit rice farming.

The purpose of this research was to determine the factors affecting the production of Inpago Unsoed-1 and Situbagendit rice varieties in Province of Central Java, and to determine the level of technical, allocative, and economic efficiencies in Inpago Unsoed-1 and Situbagendit rice farming in Province of Central Java.

\section{MATERIALS AND METHODS}

\section{Research location and samples}

Research locations were purposively determined, i.e. Province of Central Java, Indonesia as development center area for Inpago Unsoed-1 rice variety. The selected regencies were Banyumas, Purbalingga and Cilacap; while selected districts were Kalibagor (Banyumas), Kalimanah, Kemangkon, Bukateja, Kutasari, Kaligondang and Bobotsari (Purbalingga) as well as Gandrungmangu (Cilacap).

Data was collected by direct observation and interviews using a semi-structured questionnaire. Observation method was demonstrated by conducting direct observation during research activities to obtain supporting information and data either from farmers, instructors, or government officers. Interviews were conducted with Inpago Unsoed-1 rice farmers and Situbagendit who were in one area.

Respondents were collected using non-probability sampling namely purposive sampling (Margono 2004; Sugiyono 2005) in which rice farmers for respondents were purposively selected with appropriate criteria for this study, i.e. planting Inpago Unsoed-1 and Situbagendit rice varieties in the same area in the Banyumas, Purbalingga and Cilacap regencies. The research was carried out from December 2018 until May 2019. Number of samples was 147 farmers comprising 71 and 76 farmers of Inpago Unsoed-1 and Situbagendit, respectively.

\section{Analysis design}

Factors affecting the production of Inpago Unsoed-1 and Situbagendit rice farming were analyzed using functional production of Cobb-Douglas which were formulated in folowing equation : 


$$
\ln Y=\beta_{0}+\beta_{1} \ln X_{1} \beta_{2} \ln X_{2}+\beta_{3} \ln X_{3}+\beta_{4} \ln X_{4}+\beta_{5} \ln X_{5}+\beta_{6} \ln X_{6}+\beta_{7} \ln X_{7}+\beta_{8} \ln X_{8}+\varepsilon_{i}
$$

Where:

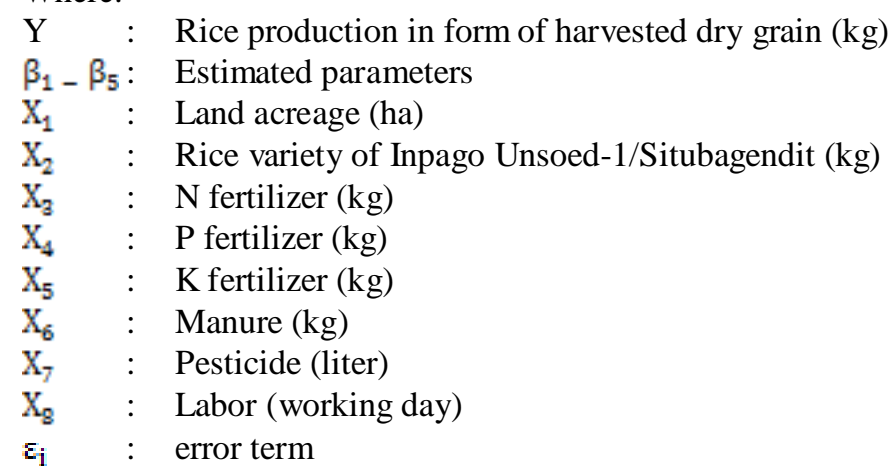

The model of regression equation from the relation of rice production of Inpago Unsoed-1 and Situbagendit varieties with affecting production factors was analyzed using method of Ordinary Least Square (OLS).
The efficiency of production in this research was tested using functional production of stochastic frontier as follows:

$$
\ln \mathrm{Y}=\beta_{0}+\beta_{1} \ln \mathrm{X}_{1}+\beta_{2} \ln \mathrm{X}_{2}+\beta_{3} \ln \mathrm{X}_{3}+\beta_{4} \ln \mathrm{X}_{4}+\beta_{5} \ln \mathrm{X}_{5}+\beta_{6} \ln \mathrm{X}_{6}+\beta_{7} \ln \mathrm{X}_{7}+\beta_{8} \ln \mathrm{X}_{8}+\mathrm{v}_{\mathrm{i}}-\mathrm{u}_{\mathrm{i}}
$$

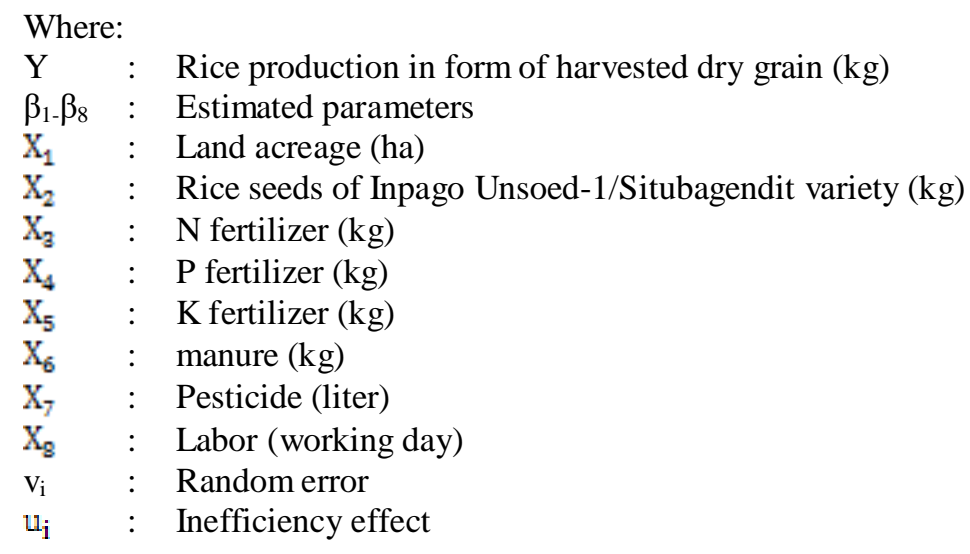

There were three measured efficiencies in this study, such as technical, allocative and economic efficiencies. Technical efficiency was calculated using the formulation:

$$
\mathrm{TE}_{\mathrm{i}}=\exp \left(-\mathrm{E}\left[\mathrm{u}_{\mathrm{i}} \mid \varepsilon_{\mathrm{i}}\right]\right) \quad \mathrm{i}=1,2, \ldots \mathrm{n}
$$

Where:

$\mathrm{TE}_{\mathrm{i}}:$ Technical efficiency of farmer $\mathrm{i}^{\text {th }}$

$\operatorname{Exp}:$ Expectation value (mean) from $u_{i}$ with (-

$\left.\mathrm{E}\left[\mathrm{u}_{\mathrm{i}} \varepsilon_{\mathrm{i}}\right]\right)$ requirement $\varepsilon_{\mathrm{i}}$, so $0 \leq \mathrm{TE} \leq 1$

That technical efficiency value was inversely correlated to value of technical inefficiency effect. Analysis of technical efficiency in this research referred to model of technical inefficiency effect developed by Coelli \& Battese (1998). Variable for measuring technical inefficiency was assumed to be free and it was normally distributed $N\left(u_{i}, \sigma^{2}\right)$.
The value of distribution parameter in technical inefficiency effect in this research was determined using following formulation:

$$
\mathrm{u}_{\mathrm{i}}=\delta_{0}+\delta_{1} \mathrm{Z}_{1}+\delta_{2} \mathrm{Z}_{2}+\delta_{\mathrm{a}} \mathrm{Z}_{\mathrm{a}}+\delta_{4} \mathrm{Z}_{4}+\delta_{5} \mathrm{Z}_{5}+\varepsilon_{\mathrm{i}(4)}
$$

Where:

$\begin{array}{lll}\mathrm{u}_{\mathrm{i}} & : & \text { Technical inefficiency effect } \\ \delta_{0}-\delta_{5} & : & \text { Coefficient affecting technical inefficiency } \\ \mathrm{Z}_{1} & : & \text { Rice varieties (1 = varietas Inpago Unsoed-1; } 0= \\ & \text { varietas Situbagendit) } \\ \mathrm{Z}_{2} & : \text { Farming experience }(\mathrm{y}) \\ \mathrm{Z}_{\mathrm{a}} & : & \text { Number of dependents (members) } \\ \mathrm{Z}_{4} & : & \text { Frequency of extension (time) } \\ \mathrm{Z}_{5} & : & \text { Dummy Side job } \\ \mathrm{\varepsilon}_{\mathrm{i}} & : & \text { Error term }\end{array}$

Economic efficiency (EE) of Inpago Unsoed-1 and Situbagendit rice farming was estimated using function of cost frontier with model specification of Cobb-Douglas Cost Frontier (Coelli and Battese 1998) : 


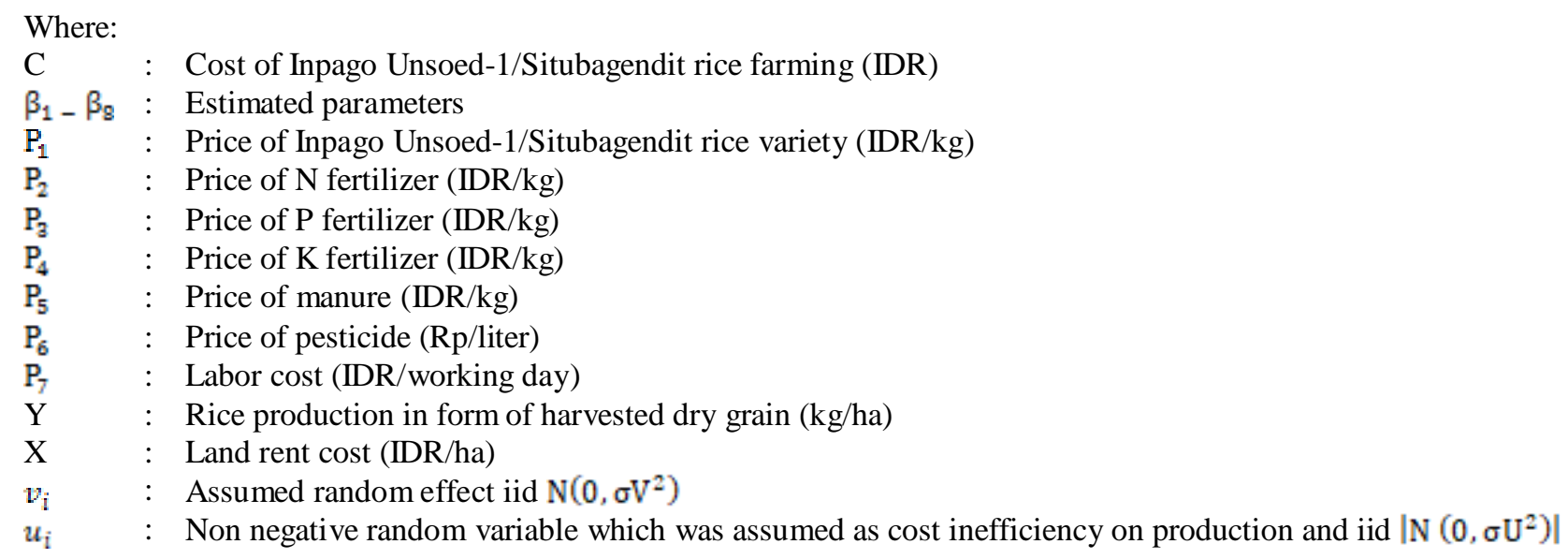

According to Coelli et al. (1996), economic efficiency was inverse of cost efficiency (CE), which was formulated as follows:

$$
\mathrm{EE}=\frac{1}{\mathrm{CE}}
$$

CE was obtained from calculation results of Frontier program software. Value of EE was between 0 and 1. Economic efficiency was the combination of technical efficiency (ET) and allocative efficiency, so that allocative efficiency (EA) was obtained from:

$$
\mathrm{EA}=\frac{\mathrm{EE}}{\mathrm{EI}}
$$

According to Soekartawi (1994), value of allocative efficiency (EA) was not always equal to 1 , frequent value of EA $>1$ showing the inefficient condition, and EA $<1$ revealing not efficient condition.

\section{RESULTS AND DISCUSSION}

\section{Factors affecting production of Inpago Unsoed-1 and Situbagendit rice farming}

Analysis of functional production was applied to figure out direct relation between production factor (input) and production (output). Functional production of Inpago Unsoed-1 and Situbagendit rice farming was assumed to have a form of Cobb-Douglas which was transformed into natural linear logarithm. The result of functional production analysis was presented in Table 1 . The result of analysis showed that obtained F-calculated for Inpago Unsoed-1 and Situbagendit rice varieties were $46.9506>6.8400$ and $50.3708>6.8400(\alpha=1 \%)$, respectively. It reflected that independent variables significantly affected their production. Constanta value revealed minimal production in case of variables influencing production were zero. According to result of analysis, Constanta values for Inpago Unsoed-1 and Situbagendit rice were 8.6320 with anti ln of 5,608.28 and 8.9280 with anti $\ln$ of 7,540.17, respectively.

Land variable had significant impact of production of Inpago Unsoed-1 and Situbagendit rice varieties at $\alpha=1 \%$ with coefficient values of 1.0303 and 1.0474 , respectively. Those values showed that the addition of land acreage might increase their production. The averages of land use for Inpago Unsoed-1 and Situbagendit rice varieties in the research location were 0.30 and 0.31 ha, respectively. Land on Inpago Unsoed-1 and Situbagendit rice farming was the most responsive variable due to its highest coefficient value. The results of this study are in line with those of previous studies (Feng 2008; Tan et al. 2010; Heriqbald et al. 2015; Shavgulidze et al. 2017; Mukwalikuli 2018; Tasila et al. 2019; Okello et al. 2019) which stated that an increase of cultivated land will have a positive impact on rice production.

Seed variable had significant effect on production of Inpago Unsoed-1 rice at $\alpha=1 \%$ with the coefficient value of- 0.3898 . This indicated that the addition of Inpago Unsoed-1 seed around 1\% would decrease the production of Inpago Unsoed-1 rice. The average of seed use for Inpago Unsoed-1 rice was $8.51 \mathrm{~kg} / \mathrm{land}$ acreage or about $29.80 \mathrm{~kg} / \mathrm{ha}$ in the field. The use of seed in research location exceeded the recommended dosage of $25 \mathrm{~kg} / \mathrm{ha}$ according to Technical Guidance for Cultivation of Inpago Unsoed-1 rice. Inpago Unsoed-1 variety is a new superior variety that has a large number of productive tillers (16 sticks). In addition, farmers in the study area used the Legowo row planting system. The Legowo row planting system used was a planting system with a spacing (25x25) $\mathrm{cm}$ between clumps in rows; $12.5 \mathrm{~cm}$ spacing in rows; and $50 \mathrm{~cm}$ distance between rows. The use of jajar legowo planting system can optimize the population of plants per ha. The current use of seeds by farmers has exceeded the recommended use of seeds, so increasing the number of seeds will not increase production, but will actually reduce production. Adding seeds will increase the number of seeds planted. so the consequence is an increase in plant density/population per ha. This is not optimal in the process of growing rice seedlings planted, because the population of seedlings in the planting hole is too much. Based on functional production of Neo Classic, the occurred condition on Inpago Unsoed-1 rice farming was at third area or irrational stage, in which the addition of input use would reduce the production (Soekartawi 1994). 
Variable of $\mathrm{N}$ fertilizer significantly affected the production of Inpago Unsoed-1 and Situbagendit at $\alpha=1 \%$ with the coefficient values of- 0.1405 and- 0.0881 , respectively. Those revealed that the addition of $1 \%$ of $\mathrm{N}$ fertilizer would decrease their production. The use of $\mathrm{N}$ fertilizer in research location for Inpago Unsoed-1 and Situbagendit was $24.05 \mathrm{~kg} / \mathrm{land}$ acreage or about 96.63 $\mathrm{kg} / \mathrm{ha}$ and $38.71 \mathrm{~kg} / \mathrm{land}$ acreage or around $129.40 \mathrm{~kg} / \mathrm{ha}$, respectively. Those applied dosages were higher than those of recommended dosage about $69 \mathrm{~kg} / \mathrm{ha}$ (according to Technical Guidance for Cultivation of Inpago Unsoed-1 rice) and $112.13 \mathrm{~kg} / \mathrm{ha}$ (according to designation reference for recommendation in use of $\mathrm{N}, \mathrm{P}$ dan $\mathrm{K}$ fertilizers at specific location of rice fields). Source of $\mathrm{N}$ fertilizer might be obtained from single and compound fertilizers such as urea and Phonska, respectively. Those fertilizers were found to be applied in the research area. The result of this study complied with previous work of Asnah (2018), in which the functional production of $\mathrm{N}$ fertilizer negatively affected the production of peanut in dryland.

Variable of $\mathrm{P}$ fertilizer significantly influenced the production of Inpago Unsoed-1 rice at $\alpha=1 \%$ with the coefficient value of 0.3233 . It indicated that the addition of $1 \%$ of $\mathrm{P}$ fertilizer would increase the production of Inpago Unsoed-1 rice. The average in use of $\mathrm{P}$ fertilizer was 8.75 $\mathrm{kg} / \mathrm{land}$ acreage or approximately $35.39 \mathrm{~kg} / \mathrm{ha}$.

Pesticide variable significantly affected the production of Inpago Unsoed-1 and Situbagenidt rice varieties with the coefficient values of $-0,0461$ at $\alpha=1 \%$ and 0.0265 at $\alpha=$ $5 \%$, respectively. Those reflected that the addition of $1 \%$ of pesticide might decrease the production of Inpago Unsoed1 rice but it could increase the production of Situbagendit rice. The average use of pesticide in research location for Inpago Unsoed-1 and Situbagendit rice varieties was 0.81 liters/acreage or around 6.08 liter/ha and 0.07 liter/acreage or about 0.28 liter/ha, respectively. There were many pest infestations during research period, primarily brown rice planthopper which was nationally epidemic at that time. Inpago Unsoed-1 was one of rice varieties that were susceptible to this pest. Actually, such conditions could be prevented earlier by cultivation technical measures in demonstrating early management of pests and diseases such as co-application of organic pesticides with first fertilization after the plant grew. This measure should be routinely implemented until harvesting. Most farmers sprayed the pesticide after the occurrence of pest was prevalent. Such strategy was not effective due to its fast transmission so that the application of pesticides could not reduce the damage on rice plants and the production of Inpago Unsoed-1 was getting decrease. In addition, farmers used chemical pesticides. The results of this study are in line with research Kea et al. (2016), which showed that pesticides have a significant effect on rice production and had a negative coefficient. According to research Kea et al. (2016), this condition occurred because the use of pesticides by farmers is inefficient. Inefficient use is caused because farmers do not have good knowledge about the dosage and use of pesticides. Meanwhile, the use of pesticides was effective in controlling pests and diseases infesting Situbagendit rice so that its production might increase. This finding was parallel with experiments of Rinaldi and Suharyanto (2014), Junaedi (2013), and Kurniawan et al. (2008), concluding that pesticides had significant impact on increasing the production. The low dosage of pesticide in Situbagendit rice farming was applied at the onset of pests and diseases on the plants. To minimize the production cost, farmers avoided spraying pesticides in case there was no infestation of pests and diseases.

\section{Analysis of technical efficiency and inefficiency}

Technical efficiency was analyzed using model of functional production of Stochastic Frontier with estimation method of Maximum Likelihood Estimate (MLE) in Frontier 4.1 program. The result of estimation on functional production of Inpago Unsoed-1 and Situbagendit rice with stochastic frontier approach was presented in Table 2.

Table 1. The result of analysis on factors affecting production of Inpago Unsoed-1 and Situbagendit rice farming in Central Java

\begin{tabular}{|c|c|c|c|c|}
\hline \multirow{2}{*}{ Variable } & \multicolumn{2}{|c|}{ Inpago Unsoed-1 } & \multicolumn{2}{|c|}{ Situbagendit } \\
\hline & Coefficient & Prob. & Coefficient & Prob. \\
\hline $\mathrm{C}$ & $8.6320 * * *$ & 0.0000 & $8.9280 * * *$ & 0.0000 \\
\hline Land Cultivated & $1.0303 * * *$ & 0.0000 & $1.0474 * * *$ & 0.0000 \\
\hline Seed Quantity & $-0.3898 * * *$ & 0.0035 & $0.1160^{\mathrm{ns}}$ & 0.2929 \\
\hline $\mathrm{N}$ fertilizer & $-0.1405 * * *$ & 0.0024 & $-0.0881 *$ & 0.0940 \\
\hline P fertilizer & $0.3233 * * *$ & 0.0000 & $0.0426^{\mathrm{ns}}$ & 0.2923 \\
\hline K fertilizer & $0.0199^{\text {ns }}$ & 0.6633 & $0.0431^{\mathrm{ns}}$ & 0.1845 \\
\hline Manure & $-0.0381^{\mathrm{ns}}$ & 0.1148 & $0.0041^{\mathrm{ns}}$ & 0.8312 \\
\hline Pesticide & $-0.0461 * * *$ & 0.0043 & $0.0265^{* *}$ & 0.0132 \\
\hline Labor & $0.1866^{\mathrm{ns}}$ & 0.1267 & $-0.0639^{\mathrm{ns}}$ & 0.5668 \\
\hline R-squared & 0.8583 & & 0.8574 & \\
\hline Adjusted R-squared & 0.8400 & & 0.8404 & \\
\hline S.E. of regression & 0.3066 & & 0.2898 & \\
\hline F-statistic & 46.9506 & & 50.3708 & \\
\hline Prob. (F-statistic) & $0.0000 * * *$ & & $0.0000 * * *$ & \\
\hline
\end{tabular}

Note: $*$ : Significant at $\alpha=10 \%$, **: Significant at $\alpha=5 \%, * * *$ : Significant at $\alpha=1 \%$, Ns: Not significant 
The values of sigma-squared and gamma in this research were 0.1793 significant at $\alpha=10 \%$ and 0.7507 significant at $\alpha=1 \%$, respectively. These values indicated that there was effect of technical inefficiency in the model and variation in value of composite error was caused by technical inefficiency component. The gamma value of 0.7507 described that $75.07 \%$ of error variation was due to technical inefficiency variable, whereas the remaining $24.93 \%$ was affected by random variable of stochastic effects, such as climate, natural disasters, infestation of pests and diseases which were involved in model.

The value of log-likelihood function MLE about37.7654 was higher than value of log-likelihood OLS around-46.5701. These described that the result of analysis was in accordance with the field condition. The value of LR test on Inpago Unsoed-1 and Situbagendit rice farming was approximately 17.6095 , higher than that on $\chi^{2}$ table of Kodde \& Palm (1986) at significant level of 5\% and value of restriction 7 was 13.401 . It revealed that function of stochastic frontier could explain the presence of technical inefficiency of farmer in production process.

Table 2 showed that variables with significant impact on inefficiency were dummy varieties, frequency of extension, and dummy side job. Dummy variety is significant at $\alpha=5 \%$, frequency of extension is significant at $\alpha=1 \%$, and dummy side job is significant at $\alpha=10 \%$.

Dummy varieties were negatively affecting the inefficiency indicating that the selection of Inpago Unsoed1 rice variety might increase the technical efficiency of rice farming. The use of superior variety could improve the production of rice farming. In this case, Inpago Unsoed-1 was one of superior rice varieties. The results showed that Inpago Unsoed-1 variety as superior variety can reduce production inefficiency. The factors that influence technical efficiency in this study can be classified into 2 namely technology and socioeconomic factors. The technological factor in this research is the use of varieties by farmers. There are 2 varieties included in this study, namely Inpago Unsoed-1 and Situbagendit. Socioeconomic factors that affect technical efficiency in research were farming experience, number of family dependents, frequency of counseling, and research. Some socioeconomic factors that can affect technical efficiency are the age of farmers, education level, labor in the family, farm size, sex, gender, experience, microcredit, training, extension (see Villano 2006; Otitoju \& Arene 2010; Akram et al. 2013; Ligeon 2013; Tung 2013; Esham 2014; Majumder et al. 2016). Technological factors in the study by Esham (2014) were dummy purchases of hybrid seeds and irrigation land ownership. The results showed that the coefficient of purchasing hybrid seeds and irrigation land ownership was negative. The negative sign on the dummy variable for purchasing hybrid seeds shows that the use of hybrid seeds is a major contributor to technical efficiency. Irrigated paddy land ownership has a negative effect, indicating that farmers who plant rice with large or small irrigation systems are more productive than farmers who do not have irrigated rice fields.

Table 2. Result of estimation on functional production of Stochastic Frontier and technical inefficiency of Inpago Unsoed-1 and Situbagendit rice farming in Central Java

\begin{tabular}{|c|c|c|c|c|}
\hline \multicolumn{2}{|c|}{ Variable } & Coefficient & Standard error & t-ratio \\
\hline \multicolumn{2}{|c|}{ Constanta } & $9.6601 * * *$ & 0.4013 & 24.0715 \\
\hline \multicolumn{2}{|c|}{ Land } & $1.1497 * * *$ & 0.1052 & 10.9246 \\
\hline \multicolumn{2}{|c|}{ Seed } & $-0.2600 * * *$ & 0.0821 & -3.1685 \\
\hline \multicolumn{2}{|c|}{$\mathrm{N}$ fertilizer } & $-0.1045^{* * *}$ & 0.0348 & -3.0041 \\
\hline \multicolumn{2}{|c|}{ P fertilizer } & $0.1746^{* * *}$ & 0.310 & 5.6419 \\
\hline \multicolumn{2}{|c|}{ K fertilizer } & 0.0365 & 0.0272 & 1.3424 \\
\hline \multicolumn{2}{|c|}{ Manure } & -0.0199 & 0.0140 & -1.4197 \\
\hline \multicolumn{2}{|c|}{ Pesticide } & 0.0062 & 0.0091 & 0.6811 \\
\hline \multicolumn{2}{|c|}{ Labor } & 0.0422 & 0.0796 & 0.5294 \\
\hline \multicolumn{5}{|c|}{ Function of technical inefficiency } \\
\hline \multicolumn{2}{|c|}{ Constanta } & $-0.6196 * * *$ & 1.0241 & 3.6320 \\
\hline \multicolumn{2}{|c|}{ Dummy Varieties } & $-0.0106^{* *}$ & 0.1507 & -2.5512 \\
\hline \multicolumn{2}{|c|}{ Experience } & 0.0153 & 0.0122 & 1.2554 \\
\hline \multicolumn{2}{|c|}{ Number of family dependents } & 0.0504 & 0.0440 & 1.1461 \\
\hline \multicolumn{2}{|c|}{ Frequency of extension } & $0.0135 * *$ & 0.0115 & 2.1113 \\
\hline \multicolumn{2}{|c|}{ Dummy side job } & $0.1984 *$ & 0.2141 & 1.8466 \\
\hline \multicolumn{2}{|c|}{ Sigma-squared } & $0.1793^{*}$ & 0.1017 & 1.7634 \\
\hline \multicolumn{2}{|c|}{ Gamma } & $0.7507 * * *$ & 0.1392 & 5.3925 \\
\hline \multicolumn{2}{|c|}{ Log-likelihood function OLS } & -46.5701 & & \\
\hline \multicolumn{2}{|c|}{ Log-likelihood function MLE } & -37.7654 & & \\
\hline \multicolumn{2}{|c|}{ LR test of the one-sided error } & 17.6095 & & \\
\hline \multicolumn{5}{|c|}{ Note: } \\
\hline$* *$ & $\begin{array}{l}\text { Significant at } \alpha=10 \% \\
\text { Significant at } \alpha=5 \%\end{array}$ & $\begin{aligned}(\mathrm{t}-\mathrm{table} & =1.0559) \\
\mathrm{t}-\mathrm{table} & =1.9772)\end{aligned}$ & & \\
\hline & Significant at $\alpha \alpha=1 \%$ & $(\mathrm{t}-\mathrm{table}=2.6117)$ & & \\
\hline
\end{tabular}


Positive impact of extension frequency variables on technical inefficiency reflected that the addition in frequency of extension and side job would increase the inefficiency in rice farming. These findings disagreed with the statement of farmers attending extension who had good access to information and technology. The average frequency of extension followed by Inpago Unsoed-1 and Situbagendit farmers in the study area was 4.3 times. The results showed that increasing the frequency of extension would increase farming inefficiencies. This condition shows that the quality of extension does not lie in large numbers or at least meetings, but the material presented and the methods used in the approach to farmers. Extension conducted so far is by holding meetings in farmer groups that are carried out routinely. Agricultural extension is a PPL (Field Agricultural Extensioner) from the District Agriculture Office. The extension material delivered is usually related to the official program, and also the problems with cultivation techniques that are being faced by farmers.

Positive impact of dummy side jobs reflected that the addition of side jobs would increase the inefficiency in rice farming. Dummy side jobs with positive effect on inefficiency revealed that farmers with side jobs would improve the inefficiency of their rice farming. Such side job might take allocated time and energy for their rice farming. Chang and Wen (2008) stated that farmers with full job in farming would more focus on managing their farming and generally had better knowledge so that they were more productive in farming. This result agreed with that of Chiona et al. (2014) in which the income from out of farming had impact on technical efficiency of maize farming in Zambia.

Technical efficiency was analyzed using model of functional production of stochastic frontier through output approach. They were categorized into the most efficient if the value was equal to or higher than 0.90 , enough efficient if the value was between 0.7 and 0.89 and not efficient if the value was less than 0.70 (Coelli \& Battese 1998). The distribution value and criteria for technical efficiency of Inpago Unsoed-1 and Situbagendit rice farming were presented in Table 3. Mean of technical efficiency on Inpago Unsoed-1 and Situbagendit rice varieties was 0.75 (with minimum and maximum values around 0.39 and 0.94 , respectively) and 0.73 (with minimum and maximum values approximately, respectively, 0.36 and 0.93 ), respectively. Those values explained that chance to produce rice at its highest potential yield until maximum one can be obtained by farmers with the most technically efficient. The technical efficiency value of Inpago Unsoed1 and Situbagendit rice farming in Central Java is lower than the value of technical efficiency of rice farming in Vietnam which has an average of 0.816 (Khai \& Yabe 2011), Alam (2015); Cambodia which has an average 0.784 (Kea \& Pitch 2016), Meenasulochani et al. (2018) but higher than research (Al-hassan 2012; Koirala et al. 2013; Oladimeji \& Abdulsalam 2013; Bhatt \& Bhat 2014; Binuyo et al. 2016; Saysay et al. 2018). Farmers of Inpago Unsoed1 and Situbagendit rice varieties might increase the technical efficiency around 25\% at technology level and input and 27\% at technology level, respectively.

Farmers of Inpago Unsoed-1 in not efficient criteria (ET < 0.70$)$ was $29.58 \%$, slightly lower than those of Situbagendit of about $30.26 \%$. Meanwhile, $7.04 \%$ of Inpago Unsoed-1 farmers were the most efficient (ET $\geq$ 0.90 ), higher than $6.58 \%$ of Situbagendit farmers. This fact described that farmers of Inpago Unsoed-1 were better in managing their rice farming, especially in determining the use of production factors for obtaining maximum output.

\section{Analysis of economic and allocative efficiencies}

The economic and allocative efficiencies were analyzed from input production side according to subjected price at the farmer level. Economic efficiency was inverse of cost function, whereas allocative (price) efficiency was ratio between economic and technical efficiencies. Cost efficiency was analyzed using model of cost function of stochastic frontier with Frontier 4.1 program. The result of model estimation on cost function of stochastic frontier on Inpago Unsoed-1 and Situbagendit rice farming in Central Java was presented in Table 4.

Table 4 showed positive value of Sigma-square $\left(\sigma^{2}\right)$ and significant at $\alpha=1 \%$, indicating the presence of compatibility between model and assumed distribution. The positive value of Gamma $(\gamma)$ parameter (0.9999), significant at $\alpha=1 \%$ described that $99.99 \%$ of variation in error term was affected by inefficient factor and $0.01 \%$ was caused by outer variables of model.

Table 3. Distribution of value and criteria for technical efficiency of Inpago Unsoed-1 and Situbagendit rice farming in Province of Central Java, Indonesia

\begin{tabular}{|c|c|c|c|c|c|c|}
\hline \multirow{2}{*}{ Interval } & & \multirow{2}{*}{ Criteria } & \multicolumn{2}{|c|}{ Inpago UNSOED-1 } & \multicolumn{2}{|c|}{ Situbagendit } \\
\hline & & & Frequency & $\%$ & Frequency & $\%$ \\
\hline$<0.70$ & & Not efficient & 21 & 29.58 & 23 & 30.26 \\
\hline 0.70 & $\begin{array}{l}-\quad 0.89\end{array}$ & Moderately efficient & 45 & 63.38 & 48 & 63.16 \\
\hline$\geq 0.90$ & & Highly efficient & 5 & 7.04 & 5 & 6.58 \\
\hline Total & & & 71 & 100 & 76 & 100 \\
\hline Min & & & 0.39 & & 0.36 & \\
\hline Max & & & 0.94 & & 0.93 & \\
\hline Mean & & & 0.75 & & 0.73 & \\
\hline
\end{tabular}


Table 4. Estimation of functional production cost of Stochastic Frontier on Inpago Unsoed-1 and Situbagendit rice farming in Central Java, Indonesia

\begin{tabular}{lrrr}
\hline \multicolumn{1}{c}{ Variable } & Coefficient & Standard-error & t-ratio \\
\hline Constanta & 0.9498 & 1.0894 & 0.8719 \\
Price of seed & 0.0662 & 0.1291 & 0.5124 \\
Price of N fertilizer & 0.0004 & 0.1348 & 0.0029 \\
Price of P fertilizer & $-0.2577^{* * *}$ & 0.0710 & -3.6294 \\
Price of K fertilizer & 0.1253 & 0.0861 & 1.4545 \\
Price of manure & $0.1183^{* * *}$ & 0.0299 & 3.9591 \\
Price of pesticide & -0.0101 & 0.0146 & -0.6913 \\
Labor cost & $0.5771^{* * *}$ & 0.1757 & 3.2844 \\
Production & $0.7123^{* * *}$ & 0.0336 & 21.1798 \\
Land rent cost & 0.1239 & 0.0761 & 1.6273 \\
Sigma-squared & $0.0496^{* * *}$ & 0.0039 & 12.7824 \\
Gamma & $0.9999^{* * *}$ & 0.0142 & 70.4130 \\
Log-likelihood function OLS & 6.0566 & & \\
Log-likelihood function MLE & 19.5788 & & \\
LR test of the one-sided error & 27.0445 & & \\
\hline
\end{tabular}

Note:

$\begin{array}{lll}* & : & \text { Significant at } \alpha=10 \% \\ * * & : & \text { Significant at } \alpha=5 \%\end{array}$

*** : $\quad$ Significant at $\alpha=1 \%$

$(\mathrm{t}-\mathrm{table}=1.6559)$

$(\mathrm{t}-$ table $=1.9773)$

$(\mathrm{t}-\mathrm{table}=2.6119)$
Model of cost function on Inpago Unsoed-1 and Situbagendit rice varieties in Central Java revealed that value of log-likelihood function using MLE method (19.5788) was higher than that of log-likelihood function using OLS method $(6,0566)$, describing cost function with MLE method was better and complied with field condition. The value of LR test on Inpago Unsoed-1 and Situbagendit rice varieties was 27.0445 , higher than the value of $\chi^{2}$ table of Kodde \& Palm (1986) at significance level $1 \%$ and value of restriction 7, i.e. 17.755, indicating that function of stochastic frontier could explain the presence of inefficiency on farmer cost in production process.

The result of estimation on cost function showed that price of $\mathrm{P}$ fertilizer, price of manure, labor cost, and production had significant impact at $\alpha=1 \%$. Negative coefficient in price of $\mathrm{P}$ fertilizer indicated that the increase in price of $\mathrm{P}$ fertilizer would reduce production cost. The source of $\mathrm{P}$ fertilizer in this study originated from SP-36, TSP, and Phonska fertilizers. The increase of fertilizer price would result in the decrease in use of $\mathrm{P}$ fertilizer so that cost of production was reduced. Expensive price caused the farmers to reduce buying the fertilizer due to their limitations in financial sources. In this study, farmers substituted the chemical $\mathrm{P}$ fertilizer with natural materials from surrounding plants as fertilizer.

Positive coefficient variables of price of manure, labor cost, and production showed that the increase in price of manure, labor cost, and production caused the increase of production cost. The use of manure in research location for Inpago Unsoed-1 and Situbagendit rice farming was 415.01 $\mathrm{kg} / \mathrm{land}$ acreage (average of $1,324.45 \mathrm{~kg} / \mathrm{ha}$ ) and 52.26 $\mathrm{kg} /$ land acreage (average of $297.29 \mathrm{~kg} / \mathrm{ha}$ ), respectively. The use of manure between Inpago Unsoed-1 and
Situbagendit farmers are different because the conditions in the field indicate that Inpago Unsoed-1 farmers who use manure are more than Situbagendit farmers. Based on the technical guidelines for Inpago Unsoed-1 cultivation, it is recommended to use manure to increase production and also reduce the use of chemical fertilizers, especially fertilizer N. Inpago Unsoed-1 farmers in the study area apply the cultivation technique, this is because the Inpago Unsoed-1 variety is new varieties known by farmers so farmers try to apply cultivation techniques according to the instructions to obtain maximum results. The increase in labor cost might increase the production cost of Inpago Unsoed-1 and Situbagendit rice farming. The average labor cost in research site was IDR55,736.00 per day. Production variable had positive impact on the increment of cost production. It was reasonable since the production had relation with farming scale, the use of superior variety, the use of production input such as fertilizer, labor, and pesticide. Large farming scale would cause high rent cost for land, the use of production input would be higher so that the purchasing cost for production input was also higher. Similarly, labor costs would increase following the increase in farming scale.

Economic efficiency was combination effect from technical and allocative efficiencies, so that farming was economically efficient if its technical and allocative efficiencies had been reached. The value of economic efficiency was the inverse from value of cost efficiency (CE). The value of allocative efficiency was obtained from technical and economic efficiencies. Distribution of values in economic and allocative efficiencies was presented in Table 5 . 
Table 5. Distribution of respondents according to value of economic and allocative efficiencies on Inpago Unsoed-1 and Situbagendit rice farming in Central Java

\begin{tabular}{|c|c|c|c|c|c|c|c|c|c|}
\hline \multirow{3}{*}{ Interval } & \multirow{3}{*}{ Criteria } & \multicolumn{4}{|c|}{ EE } & \multicolumn{4}{|c|}{ EA } \\
\hline & & \multicolumn{2}{|c|}{ Inpago UNSOED-1 } & \multicolumn{2}{|c|}{ Situbagendit } & \multicolumn{2}{|c|}{ Inpago UNSOED-1 } & \multicolumn{2}{|c|}{ Situbagendit } \\
\hline & & Frequency & $\%$ & Frequency & $\%$ & Frequency & $\%$ & Frequency & $\%$ \\
\hline $0.39-0.69$ & Not efficient & 42 & 59.15 & 69 & 90.79 & 11 & 15.49 & 25 & 32.89 \\
\hline $0.70-0.89$ & Moderately efficient & 25 & 35.21 & 6 & 7.89 & 31 & 43.66 & 40 & 52.63 \\
\hline $0.90-1.70$ & Highly efficient & 4 & 5.63 & 1 & 1.32 & 29 & 40.85 & 11 & 14.47 \\
\hline Total & & 71 & 100 & 76 & 100 & 71 & 100 & 76 & 100 \\
\hline Min & & 0.35 & & 0.33 & & 0.49 & & 0.40 & \\
\hline Max & & 1.00 & & 0.92 & & 1.70 & & 1.41 & \\
\hline Mean & & 0.65 & & 0.54 & & 0.88 & & 0.75 & \\
\hline
\end{tabular}

The results of distribution on value of economic efficiency of Inpago Unsoed-1 rice farmers was $59.15 \%$ (not economically efficient), 35.21\% (moderately efficient) as well as $4 \%$ (highly efficient). The mean economic efficiency of Inpago Unsoed-1 rice farmers of 0.65 was included in the inefficient category. The lowest economic efficiency value of Inpago Unsoed-1 farmers was 0.35 , and the highest economic efficiency value was 1.00. This shows that the farmers in the sampling areas, on average, can achieve maximum efficiency by saving costs by $35 \%$ (1-0.65/1.00). The results of the distribution on value of economic efficiency of Situbagendit rice farmers were 90.79\% (not economically efficient), $7.89 \%$ (moderately efficient), and $1.32 \%$ (highly efficient). The mean economic efficiency of Situbagendit rice farmers of 0.54 was included in the inefficient category. The lowest economic efficiency value of Situbagendit rice farmers was 0.33 , and the highest economic efficiency value was 0.92 . This shows that the farmers in the sample on average can achieve maximum efficiency by saving costs by $44.90 \%$ (1-0.54/0.92) (Ogundari and Ojo 2006).

The result of distribution of values of allocative efficiency of Inpago Unsoed-1 farmers showed that $15.49 \%$ of farmers were not allocatively efficient, $43.66 \%$ were moderately efficient, and $40.85 \%$ were highly efficient. The mean allocative efficiency of Inpago Unsoed-1 rice farmers was 0.88 , included in the quite efficient category, the lowest efficiency value was 0.49 and the highest value was 1.70 . This means that, if the average value of respondent farmers can reach the highest level of allocative efficiency, then they can save costs by $48.24 \%$ (1$0.88 / 1.70)$, while the most inefficient farmers can save costs by $71.18 \%$ (1-0.49/1.70) [Ogundari \& Ojo 2006); Anggraini et al (2017). The results of the allocative efficiency distribution of Situbagendit farmers showed that $32.63 \%$ of farmers were not allocatively efficient, $52.63 \%$ were moderately efficient, and $14.47 \%$ were highly efficient. The average allocative efficiency of Situbagendit farmers was 0.75 included in the quite efficient category, the lowest efficiency value is 0.40 and the highest efficiency value is 1.41 . This meaning that if the average value of respondent farmers can reach the highest level of allocative efficiency, then they can save costs by $46.81 \%$
(1-0.75/1.41), while the Sitebagendit farmers who are the most inefficient can save costs by $71.63 \%$ ( $1-0.40 / 1.41)$.

The value of technical, allocative, and economic efficiency of Inpago Unsoed-1 rice farming was, respectively, $0.75,0.88$, and 0.65 . The technical efficiency and allocative value of Inpago Unsoed-1 rice farming were included in moderately efficient category. The technical efficiency value of Inpago Unsoed-1 rice farming is smaller than the allocative efficiency value (TE <EA) which shows that Inpago Unsoed-1 farmers have paid attention to the price for each input but are technically inefficient. This has an impact on the low value of economic efficiency (Anggraini et al. 2017). The results of this study are also consistent with research conducted by Nwaru et al. (2011). The value of technical, allocative, and economic efficiency of Situbagendit rice farming was $0.73,0.75,0.54$. The value of technical efficiency and allocative Situbagendit rice farming are included in moderately efficient category. The technical efficiency value of Situbagendit rice farming is smaller than the allocative efficiency value (TE <EA) which indicates that Situbagendit farmers have paid attention to the price for each input but technically it has not been efficient. This has an impact on the low value of economic efficiency (Anggraini et al. 2017). The results of this study are also consistent with research conducted by Nwaru et al. (2011).

In conclusion, production factors that have a significant effect on Inpago Unsoed-1 rice production are land acreage, $\mathrm{P}$ fertilizer (positive impact); seeds, $\mathrm{N}$ fertilizer, and pesticides (negative impacts). For Situbagendit rice, land acreage and pesticides have a positive effect, while $\mathrm{N}$ fertilizer has a negative impact. The efficiency of Inpago Unsoed-1 and Situbagendit rice production is moderately efficient but not economically efficient. Inpago Unsoed-1 rice farming has a higher efficiency value than Situbagendit rice farming. Increasing production efficiency can be done by reducing the use of excess production factors, namely seeds, $\mathrm{N}$ fertilizers, and pesticides by applying cultivation techniques according to the Ministry of Agriculture's recommendations. Factors related to production efficiency are variety, frequency of extension, and side jobs dummy. The use of Inpago Unsoed-1 varieties can increase production efficiency so that the Inpago Unsoed-1 variety can be recommended as a superior variety that can improve 
farm production efficiency. Another policy that can be done to improve production efficiency is to improve the quality of extension activities. Improving the quality of outreach can be done by prioritizing the provision of extension materials on the use of production factors that can increase rice production, as well as variations inappropriate socialization and targeted extension methods, for example by using demonstrations and demonstration plots.

\section{ACKNOWLEDGEMENTS}

The authors would like to acknowledge the following related parties: Ministry of Finance through the LPDP for scholarship supports of BUDI-DN during Doctoral Program in Universitas Gadjah Mada, Yogyakarta, Indonesia. All respondent farmers of Inpago Unsoed-1 and Situbagendit in Central Java. Agriculture instructor in Central Java for assistance in this research.

\section{REFERENCES}

Achandi EL. 2018. Technical efficiency: A study of smallholder rice farmers in Kilombero district, Tanzania. J Econ Bibliography 5(3): 193-208.

Addison M, Ohene-yankyera K, Fredua-antoh E. 2016. Gender role, input use and technical efficiency among rice farmers at Ahafo Ano North District in Ashanti Region of Ghana. J Food Secur 4(2): 27-35.

Akram W, Hussain Z, Ahmad N, Hussain I. 2013. Does agriculture credit affect production efficiency? Frontier production function approach. Pak Econ Soc Rev 51(2): 179-190.

Alam MN. 2015. Socio-economic and technical efficiency level of organic rice farming with system of rice intensification: A case study in Morowali regency Indonesia. Am J Appl Sci 12(4): 290-294.

Al-Hassan S. 2012. Technical efficiency in smallholder paddy farms in Ghana : an analysis based on different farming systems and gender. J Econ Sustain Dev 3(5): 91-106

Anggraini N, Harianto H, Anggraeni L. 2017. Efisiensi teknis, alokatif dan ekonomi pada usahatani ubikayu di Kabupaten Lampung Tengah Provinsi Lampung. Jurnal Agribisnis Indonesia, 4(1): 43-56. DOI:10.29244/jai.2016. [Indonesian]

Asnah. 2018. Efficiency, Risk and Risk Behavior of Corn and Peanut Farming with Biochar Application in South Blitar Dry Land [Disertation]. Universitas Gadjah Mada, Yogyakarta. [Indonesian]

Bhatt MS, Bhat SA. 2014. Technical efficiency and farm size productivity - micro-level evidence from Jammu \& Kashmir. Int J Food Agric Econ 2(4): 27-49.

Bhattacharyya AR, Mandal. 2016. A generalized stochastic production frontier analysis of technical efficiency of rice farming a case study from Assam, India. Indian Growth Dev Rev 9(2): 114-28.

Binuyo G, Abdulrahman S, Yusuf O et al. 2016. Technical efficiency of rain-fed lowland rice production in Niger State, Nigeria. Asian $\mathrm{J}$ Agric Extension Econ Sociol 9(4): 1-12. DOI: 10.9734/ajaees/2016/22504

Chandio AA, Jiang Y, Gessesse AT et al. 2019. The nexus of agricultural credit, farm size and technical efficiency in Sindh, Pakistan: A stochastic production frontier approach. J Saudi Soc Agric Sci 18(3): 348-354.

Chang H, Wen F. 2008. Off-farm work, technical efficiency, and production risk: empirical evidence from national farmer survey in Taiwan. Am Agric Econ Assoc, Orlando, Florida: 269-278.

Coelli TJ. 1996. A Guide to Frontier Version 4.1: A Computer Program for Stochastic Frontier Production and Cost Function Estimation. Center For Efficiency and Productivity Analysis. University of New England. Armidale. New South Wales.

Coelli T, Rao DSP, Battese GE. 1998. An Introduction to Efficiency and Productivity Analysis, Second. Springer US, Boston, MA.
Coventry DR, Poswal RS, Yadav A, et al. 2015. A comparison of farming practices and performance for wheat production in Haryana, India. Agric Syst 137: 139-153.

Efani A, Soemarno, S Muhammad, et al. 2019. Technical efficiency evaluation of tuna fishing biology using stochastic frontier production function. Eur Asian J Biosci 13: 363-368.

Esham M, 2014. Technical efficiency and determinants of maize production by smallholder farmers in the Moneragala district of Sri Lanka. Mediterr J Soc Sci 5(27): 416-422.

Feng S. 2008. Land rental, off-farm employment and technical efficiency of farm households in Jiangxi Province, China. NJAS-Wageningen J Life Sci 55(4): 363-378.

Gong TC, Battese GE, Villano RA. 2019. Family farms plus cooperatives in China: Technical efficiency in crop production. J Asian Econ 64: 112. DOI:10.1016/j.asieco.2019.07.002

Goyal SK, Suhag KS, Pandey UK. 2006. An estimation of technical efficiency of paddy farmers in Haryana state of India. Indian Journal of Agricultural Economics 61(1): 108-122.

Hanafie R. 2010. Introduction to Agricultural Economics. Andi Publisher, Yogyakarta. [Indonesian]

Heriqbaldi U, Purwono R, Haryanto T, et al. 2015. An analysis of technical efficiency of rice production in Indonesia. Asian Soc Sci 11 (3): 91-102.

Junaedi. 2013. Production Efficiency, Farmer Behavior and Competitiveness of Smallholder Cotton Farming in South Sulawesi. [Disertation]. UGM. Yogyakarta. [Indonesian]

Kalirajan KP. 1996. Farm specific technical efficiencies and development policies. J Econometrics Stud 11(1): 3-13.

Kea S, Li H, Pich L. 2016. Technical efficiency and its determinants of rice production in Cambodia. Economies, 4(4): 22. DOI:10.3390/economies4040022

Kerdsriserm C, Suwanmaneepong S, Mankeb P. 2018. Comparative analysis of the technical efficiency of different production systems for rice farming in Eastern Thailand. Asian J Sci Res 11(4): 480-488.

Khai HV, Yabe M. 2011. Technical efficiency analysis of rice production in Vietnam. J ISSAAS (17): 135-146.

Kodde DA, Palm FC. 1986. Wald criteria for jointly testing equality and inequality restriction. Econometrica Vol 54 No. 5: 1243-1248.

Koirala KH, Mishra AK, Mohanty S. 2013. Determinants of rice productivity and technical efficiency in the Philippines. Southern Agricultural Economics Association (SAEA) Annual Meeting, October 2015. DOI: 10.13140/2.1.3275.1360

Kouyate D, Savadogo K, Cachia F. 2019. Effects of irrigation modes on technical efficiency of rice farmers in Mali. J Agric Environ Sci 8(1): 129-139.

Kurniawan AY, S Hartoyo, Syaukat. 2008. Analysis of the efficiency and competitiveness of corn farming on dry land in Tanah Laut Regency, South Kalimantan. Post Graduate Forum Journals 31(2): 93-103. [Indonesian]

Ligeon C. 2013. Production efficiency and risks in limited resource farming: The case of Bulgarian peanut industry. J Dev Agric Econ 5(4): $150-160$

Lubis SN. 2000. Adoption of Technology and Factors Affecting it. USU Press, Medan. [Indonesian]

Majumder S, Bala BK, Arshad FM et al. 2016. Food security through increasing technical efficiency and reducing postharvest losses of rice production systems in Bangladesh. Food Secur 8: 361-374.

Margono. 2004. Educational Research Methodology. Rineka Cipta, Jakarta. [Indonesian]

Meenasulochani R, Rajendran T, Pushpa J, et al. 2018. Technical efficiency of paddy production and factors affecting the efficiency in Nagapattinam District, Tamil Nadu. Int J Agric Innov Res 6(6): 355 358.

Mukwalikuli, M. 2018. Determinants of technical efficiency of smallholder farming in Lukulu. World J Res Rev 6(4): 60-65.

Nezhad MZ, Bavarsad B, Mohamad S, et al. 2012. Study of the technical efficiency of rice farmers in Iran: a case of Kohgiluyeh and BoyeAhmad Province. Q J Quant Econ 8(4): 87-118.

Nguyen TT, Ngu VH, Seo B. 2012. Cost and environmental efficiency of rice farms in South Korea. Agric Econ 43: 367-376.

Nguyen HQ. 2017. Analyzing the economies of crop diversification in rural Vietnam using an input distance function. Agric Syst 153: 148156

Nwaru JC, Okoye BC, Ndukwu PC. 2011. Measurement and determinants of production efficiency among small-holder sweet potato (ipomoea batatas) farmers in Imo State, Nigeria. European Journal of Scientific 
Research 59 (3): 307-317.

Ogundari, K., \& Ojo, S. 2006. An examination of technical, economic and allocative efficiency of small farms: The case study of cassava farmers in Osun State of Nigeria. Bulgarian Journal of Agricultural Science 7(3): 423-432.

Okello DM., Bonabana WJ, Mugonola B. 2019. Farm-level allocative efficiency of rice production in Gulu and Amuru districts, Northern Uganda. Agric Food Econ 7(1): 1-19. DOI:10.1186/s40100-0190140-X

Oladimeji YU, Abdulsalam Z. 2013. Analysis of technical efficiency and its determinants among small scale rice farmers in Patigi local government area of Kwara State, Nigeria. IOSR J Agric Vet Sci 3(3): 34-39.

Otitoju MA, Arene CJ. 2010. Constraints and determinants of technical efficiency in medium-scale soybean production in Benue State, Nigeria. Afr J Agric Res 5(17): 2276-2280.

Paul S, Shankar S. 2018. On estimating efficiency effects in a stochastic frontier model. Eur J Operational Res 271(2): 769-774.

Rasyid MN, B Setiawan, MM Mustadjab, et al. 2016. Factors that influence rice production and technical efficiency in the context of an integrated crop management field school program. Am J Appl Sci 13: 1201-1204.

Rinaldi, Jemmy, Suharyanto. 2014. Risk analysis and the factors that influence it in cocoa farming in Bali; Proceeding of National Seminary: Food and Agriculture Sovereignty. Gadjah Mada University, Yogyakarta, 6 December 2014. [Indonesian]

Samarpitha A, N Vasudev, K Suhasini. 2016. Technical, economic, and allocative efficiencies of rice farms in Nalgonda district of Telangana state. Econ Affairs 3:365-374.

Saysay JL, Gabagambi DM, Mlay GI et al. 2018. Technical Efficiency in Rice Production Among Smallholder Farmers in Central Liberia: A Stochastic Production Frontier Analysis. J Econ Sustain Dev 9(20): 47-53.
S Chiona, Th Khalinda, G Tembo. 2014. Stochastic frontier analysis of the technical efficiency of smallholder maize farmers in Central Province. Zambia. J Agric Sci 6 (10): 108-118. DOI: 10.5539/jas.v6n10p108

Shavgulidze R, Bedoshvili D, Aurbacher J. 2017. Technical efficiency of potato and dairy farming in mountainous Kazbegi district, Georgia. Ann Agrarian Sci 15(1): 55-60.

Soekartawi. 1994. Economic Theory of Production with Cobb-Douglas Analysis Discussion. Raja Grafindo Perkasa, Jakarta. [Indonesian]

Sugiyono. 2005. Understanding Qualitative Research . Alfabeta, Bandung. [Indonesian]

Sukirno S. 2009. Microeconomics Introduction Theory Third Edition. Rajawali Press, Jakarta. [Indonesian]

Tan S, Heerink N, Kuyvenhoven A, et al. 2010. Impact of land fragmentation on rice producers' technical efficiency in South-East China. NJAS-Wageningen J Life Sci 57(2): 117-123.

Tasila KD, Mabe FN, Alhassan H. 2019. Technical and resource-useefficiency among smallholder rice farmers in Northern Ghana. Cogent Food Agric 5(1): 1-15.

Tung DT. 2013. Changes in the technical and scale efficiency of rice production activities in the Mekong delta. Agric Food Econ 1 (16): 111.

Villano R, Fleming E. 2006. Technical Inefficiency and Production Risk in Rice Farming: Evidence from Central Luzon. Asian Econ J 20 (1): 29-46. DOI: $10.1111 / \mathrm{j} .1467-8381.2006 .00223 . \mathrm{x}$

Wibowo RP, Raihan A, Sumono, et al. 2019. Comparative analysis of technical efficiency between organic and non-organic rice farming in North Sumatera Indonesia. IOP Conf Ser Math Sci Eng 648: 012038. DOI: $10.1088 / 1757-899 \mathrm{X} / 648 / 1 / 012038$

Zhang SC, Wei CF, Shao JA, Wu ZJ. 2016. Technical efficiency and its determinants of the various cropping systems in the purple-soiled, hilly region of southwestern China. J Mount Sci 13 (12): 2205-2223. 